\title{
Citizen-Centric Public Service Satisfaction During Pandemic Outbreak: A Measurement Model
}

\author{
Siti Daleela Mohd Wahid \\ Fac. of Business Management, Universiti Teknologi MARA \\ 78000, Melaka, Malaysia. \\ E-mail: sitid365@uitm.edu.my
}

Siti Hajjar Mohd Amin

Fac. of Administrative Science \& Policy Studies, Universiti Teknologi MARA

40450 Selangor, Malaysia.

E-mail: hajjar@uitm.edu.my

Abdul Jalil Mohamed Ali

Fac. of Administrative Science \& Policy Studies, Universiti Teknologi MARA

40450, Selangor, Malaysia

E-mail: ajalil838@uitm.edu.my

\begin{abstract}
Aida Abdullah
Fac. of Administrative Science \& Policy Studies, Universiti Teknologi MARA 40450, Selangor, Malaysia.

E-mail: aida547@uitm.edu.my
\end{abstract}

Siti Mariam Ali

Fac. of Business Management, Universiti Teknologi MARA 78000, Melaka, Malaysia.

E-mail: smali@uitm.edu.my 
Siti Noraziana Azis

Fac. of Business Management, Universiti Teknologi MARA 78000, Melaka, Malaysia.

E-mail: noraziana@uitm.edu.my

Received: Aug. 26, 2020 Accepted: Sep. 30, 2020 Online published: Nov. 10, 2020

doi:10.5296/jpag.v10i4.17586

URL: https://doi.org/10.5296/jpag.v10i4.17586

\begin{abstract}
Citizen-centricity satisfaction is a recent phenomenon spreading around the world. It is of growing interest to scholars and many papers are focused on this area. This paper aims at revealing factor that predict a citizen satisfaction during pandemic outbreak in public service delivery. A massive number of theories and past scholars have carried out studies on the factors influencing citizen satisfaction, which resulted in a list containing large volume of variables. There was a need to generalize factors that capable to form a universal citizen satisfaction model. This research utilizing citizen-centric demands of transformational government model as the theoretical foundation in citizen satisfaction in public service context. 346 citizens conveniently were selected as respondents, at the same time as information become amassed via online surveys. The information become then analyzed via the use of AMOS software. The structural equation modelling (SEM) was executed to develop the measurement model. The results exhibit that goodness of fit, construct reliability, convergent validity and discriminant validity achieved the overall fitness threshold to model citizen satisfaction. This research contributes to shed light on the literature via examining the elements of citizen-centric demands of transformational government model namely openness, responsiveness, transparency and participation in citizen satisfaction.
\end{abstract}

Keywords: citizen-centric, satisfaction, public service, openness, responsiveness, transparency, participation, covid-19

\title{
1. Introduction
}

Governments must prioritize the rising issues of poverty, inequality, and marginalization in developing countries that often have difficult choices to address evolving social needs at the same time (Kumar, 2019). In addition, several public agencies struggle to sufficiently satisfy the citizen's expectation of offering numerous critical services that eventually contribute to failure of public service (Van de Walle, 2004, 2016), and this situation causes people to fall into insecure roles (Ma \& Christensen, 2019). Therefore, in public sector reform efforts, a long-debated problem of citizens' dissatisfaction with public services is continually highlighted (Van de Walle, 2017). Citizens' perceptions of government services grew in 
parallel with the high starting points of public satisfaction with services, fiscal health, and young populations (OECD \& ADB, 2019). The power and right to govern will be lost if they do not fulfil the criteria and lead to dissatisfaction (Mok, 2020).

The recent political transitions and the pandemic crisis have caused the nation to collapse into severe shock. With the outbreak of Covid-19, the new government of Malaysia has entered a perfect storm of global and national economic problems with severe socio-political consequences. "Covid-19 represents the new government's first, biggest and most visible test of competence. Any failures, perceived or real, will further affect the legitimacy of this government." (Bowie, 2020, March 16). As we can see, the way our government reacts to, regulates and interacts about crises has direct effects for public well-being and eventually influences public opinion or attitudes about local governments and government officials (Avery et al., 2016). For that reason, by providing several stages of PRIHATIN economic stimulus packages, the Malaysian government made swift decisions to ease the burden of all Malaysians (Ministry of Finance Malaysia, 2020). Therefore, multiple unpopular actions implement by government to prevent the spread of COVID-19 in the country.

Jakobsen et al. (2016) that people play a vital role in public administration because they are the end-user of government compliance policies/rules/programs, and essentially people are the final evaluator of these outputs. Therefore, regardless of good services or high-end technologies, to be citizens-centric, consumers ('citizens' in the case of public service delivery processes) must be the cornerstone of the design approach (Malhotra, 2015) and strategic planning (Kopackova, 2019). Even though, people from different socio-economic groups may encounter a similar public service level; still, they may draw different conclusions about service because their perceptions are influence by multiple sets of perceived results and expectations Song et al. (2020).

According to the Organization for Economic Cooperation and Development report (OECD \& ADB, 2019), the government must meet several requirements to assert a citizen-centric government. Criteria such as efficiency, responsiveness, accountability, continuous improvement of its control, honesty, promotion of justice, and inclusive policymaking are required. Following similar trend, numerous of factors have been listed by past scholars that influence the public service satisfaction such as openness and responsiveness (Black \& La Venture, 2018; Kamaruddin \& MdNoor, 2017), participation and transparency (Kamaruddin \& MdNoor, 2017), effectiveness and efficiency (Reddick et al., 2017; Sanka et al., 2019), learnability (Reddick et al. (2017), usefulness (Naswir et al., 2019; Sánchez-Teba \& Bermúdez-González, 2019) and perceived usability of government services (Naswir et al., 2019). However, at the moment, little is known how those factors play significant role in assisting government strategies in providing citizen-centric public service satisfaction.

On the other hand, the scholars view that most of the citizen-centric studies have been heavily focuses on e-government/e-governance services (Agbozo \& Spassov, 2018; Das \& Mishra, 2018; Jun et al., 2018; Kyakulumbye et al., 2019; Malchenko \& Smirnova, 2019; Misra et al., 2018; Naswir et al., 2019; Sánchez-Teba \& Bermúdez-González, 2019; Sanka et al., 2019; Sepasgozar et al., 2019; Sneiders et al., 2018).Yet, little is known about centric-centric 
approach being measure upon citizen satisfaction.

Therefore, this study advances into two aspects. Firstly, we utilized the factors of Citizen-Centric Demand of Transformational Government in which being categorise as the most studied factors to form holistic citizen centric public service satisfaction model and secondly, this study is focused at national-level context whereby will benefited for future avenue as suggested by the previous scholars.

\section{Literature Review}

\subsection{The Emerging of Citizen-Centric}

Citizen-centricity is about moving the government's focus from the eyes of the citizens to service delivery (the needs of people come first) rather than the organisational problems or other imperatives of the government (Gupta, 2006). Instead of asking what resources government agencies should offer, policymakers need to start with what people actually need. In other words, there has to be a distinct shift from an "agency centric" model to a "citizen centric" model (Yong, 2004). Citizen-centric principles include the design of public services to meet the needs of people, openness of information for easy access, and consistency in service delivery. (Cai \& Wang, 2006).

The development of citizen-centric can be seen through changes of public administration regimes. A minimum of three public administration improvements has been reported by Sicilia et al. (2016). First, the government focuses on improving efficiency of the bureaucracy, it is known as Traditional Public Administration (TPA), here, citizen is considered as a passive recipient of public services (Fry \& Nigro, 1996). Second, by encouraging corporatization and privatization to give more attention to the needs of end-users, the government is increasingly adopting the style of private management known as New Public Management (NPM), where citizen have more options as customers to receive quality services (Hood, 2001). Third, New public governance (NPG) has emerged, allowing for more collaborative processes among multiple interdependent actors to facilitate inclusive policymaking through this administrative reform. Most of the government called for the co-development of service users and the public to increase the production of public services that enable people to engage effectively in decision-making by the government (Robinson, 2015).

In strategic planning, the citizen-centric approach calls for respecting the needs of citizens and the hierarchy of needs of Maslow reflects essential viewpoints that identify and prioritize the needs of citizens (Kopackova, 2019). However, acknowledging the prevalent scenario in developed countries, the government still follows a top-down approach and is generally recognized as a passive consumer by people, which eventually contributes to administrative production wastage (Kyakulumbye et al., 2019).

\subsection{The Importance of Citizen-Centric Approach in Public Service}

According to the Organisation for Economic Cooperation and Development (OECD, 2019), government able to achieve citizen-centric approach for policy making and service delivery 
through coordination between agencies and make use of using user preference data, being transparent and allowing for more active involvement among stakeholders and producing right policy and expenditure choices towards responding to the citizen needs. On the other hand, Naswir et al. (2019) have empirically found that effectiveness, efficiency, learnability, satisfaction, usefulness, and citizen centric are key factors of perceived usability of government services. Similarly, Sanka et al. (2019) revealed that by providing smart, citizen centric, ethical, efficient and effective governance help to directly produce transformational impact onto the government services, whilst assist indirectly the citizen through transparency, accountability, convenience and friendliness.

Reddick et al. (2017) developed a framework for facilitating organizational learning through social media text analytics to enhance citizen-centric public service quality based on double-loop learning orientation theory. Unfortunately, government agency still using one-way communication in Facebook page and not utilizing their direct and meaningful citizen participation of social media platform in the city's recycling governance. Alternatively, Malchenko and Smirnova (2019) developed citizen-centric bottom-up typology of smart services, focus on digital natives as the principal consumers of smart city solutions as a guideline for future researchers and smart city administrator for better categorization of technology and human-driven approach. Interestingly, opinion poll conducted by Sánchez-Teba and Bermúdez-González (2019) among 475 residents of the city of Malaga (Southern Spain) have high expectation on the use of technology in smart city towards improving quality of life, followed by mobility and improved governance.

Beside technology as the main driver of citizen-centric approach, public sector employees are the most important asset as they are implementers of government policies and strategies. Giesbrecht et al. (2016) developed an advisory information artefact, a comprehensive on-the-job support system for government front offices and through action design research, it is proven this system able to help their front offices change from providing government-centric, transaction-oriented processing services to offering high level and citizen-centric advising. conceptually identified people-first core values, leadership, open communication, trust, aligned operations and work environments, change responsiveness, and organizational resiliency demonstrate important elements of people-centred organizational cultures which promote to better productivity and profitable working environment. This is supported by the study conducted by Nor et al. (2017), the authors developed Citizen Centric Public Service Towards Excellence in the pursuit of engaging public sector employees to meet never-ending citizen demand. Empirically, strategy; people, products, partnerships and resources; work environment; well-being; and work-life balance are significant and positive relationship with citizen-centric public service among Malaysian governmental agencies.

Nutshell, the recent literature on citizen-centric concept recommended government can be more citizen-centric through continuously improve performance, strategic planning, inclusive governance and the usage of technology able to bridge the relationship and driver to deliver citizen-centric service at higher level. Meanwhile, citizen satisfaction is vital to determine effectiveness of citizen-centric strategies perform by government and citizen participation is the popular medium found in many studies in relative to citizen-centric concept. As per 


\section{Ml Macrothink}

Journal of Public Administration and Governance

ISSN 2161-7104

2020, Vol. 10, No. 4

suggestion by OECD and ADB (2019), we are proposing a citizen-centric public service satisfaction model which benefited both parties - public service provider and citizen's satisfaction.

\subsection{Citizen-Centric Demand of Transformational Government}

The Citizen-centric demands of transformational government model on this research was centred based on the issues of poor take-up of government services, lack of public trust and difficulties in measuring efficiency gains. A citizen-centric demand model for transformational government contains the components known as openness, transparency, participation and responsiveness. It has been said that the model is developed to help government's supply side to design services that fulfil the needs of its citizens. Unfortunately, until today, we found the items have not been systematically investigated and empirically tested. Thus, Kamaruddin and MdNoor (2017) recommended to hypothesize and test relationship between the components so that targeted users can get a holistic view of the model. Following the suggestion, we empirically provide the evidence which we contextualise from the perspective of citizen satisfaction study.

Table 1. Conceptual Model for Citizen-centric Demands of Transformational Government

\begin{tabular}{llll}
\hline $\begin{array}{l}\text { Citizen-centric } \\
\text { requirements }\end{array}$ & Characteristics & Features desired & Examples \\
\hline Openness & $\begin{array}{l}\text { Government provide } \\
\text { free access to its } \\
\text { structured and } \\
\text { unstructured data }\end{array}$ & $\begin{array}{l}\text { - Machine-readable, easily } \\
\text { categorize, indexed and } \\
\text { sharing what it is about, }\end{array}$ & $\begin{array}{l}\text { (UK) Data.gov.uk } \\
\text { (US) Apps for } \\
\text { democracy }\end{array}$ \\
& & - Cpenness by default, & \\
& & complex tools to & \\
& & manipulate data & \\
\hline Transparency & Government provide & - Honest, simple to & (Sweden) Debat \\
& information about & understand and relevant & Almhut \\
their operations and & information & (USA) Sandy \\
& decisions to their & - Be clear what information & transparency portal \\
& public & can't be released & \\
& & - Clear and traceable process & \\
& & flow & \\
\hline Participation & Citizen contribute in & - Give direct benefits to & (Singapore) Public \\
& government planning & citizens & Consultation Portal \\
& and decision making & - Control of participation & (UK) Love Clean \\
& and use government & process & Streets \\
& data to create better & - A proper framework and & \\
& service & guidelines in place & \\
& & - Engaging contents to & \\
& & interest citizens & \\
\hline Responsiveness & Government listens to & - Real-time communication & (Australia) vic.gov.au \\
\hline
\end{tabular}


citizens' feedback and - In easy and simple to

acknowledges it understand messages

(UK)BusinessGov.UK

- Enforcement of service

level agreement

- Culture change in public

sector

Sources: Kamaruddin and MdNoor (2017)

\section{Material and Method}

\subsection{Population and Sample Procedures}

This study population consisted of Malaysian citizen. The respondents were varied from students, unemployed, self-employed until public and private employees. A study was conducted among the 346 citizens in Malaysia. Surveys were administered through online survey (Google form). Citizen were randomly selected and asked to willingly contribute in a research project. Data collection took place in 15 June 2020 and lasted for two weeks. The current study employed the non-probability sampling category namely convenience sampling technique. During this stage, we aimed citizens who had experienced of using service at any Municipal Council Counter in Malaysia. In terms of sample size, there are few guidelines that have been suggested by past researchers. After considering their suggestions, we considered 300 samples.

\subsection{Measurement and Scaling of the Theoretical Construct}

This study employed an online survey questionnaire. The online survey questionnaire was designed into three (3) sections. The questions in section A covered the demographic profile. The questions covered the background of citizens, such as gender, age, race, marital status, education levels, sectors and working tenure were all collected in this study. The question in Section B covered the exogenous variables namely openness, responsiveness, transparency and participation which we adapt from the literature documentation of Kamaruddin and MdNoor (2017). While in section C, the items of satisfaction level adapted and improvised from Grimmelikhuijsen and Porumbescu (2017). Thereafter, it was edited to suit the context of citizen-centric public service satisfaction study. The entire instrument was using a 7-Likert scale ranging from 1 (Completely Disagree) to 7 (Completely Agree) which were used to measure the items.

\subsection{Analytical Strategy}

In this paper, there two-stage analysis involve. Firstly, we executed Descriptive Analysis via Statistical Package for the Social Sciences (SPSS) software for analysing data. This software is user friendly with the computing engine for analysing constructs which consist of multiple underlying concepts (Byrne, 2016; Hair et al., 2018). Analysing and testing a theory using SPSS software is fast, efficient and user-friendly (Hair et al., 2018).

Secondly, Structural Equation Modelling (SEM) is employed. According to Hair, Black, Babin \& Anderson (2018), Structural Equation Modelling (SEM) "is the best multi variate 
procedure for testing both the construct validity and theoretical relationships." SEM is used as a more powerful approach as compared to multiple regressions, path analysis, factor analysis, time series analysis, and analysis of covariance. (Hair et al., 2018) added that by using SEM, the strength of associations between constructs could be identified more accurately because it considers measurement errors.

Moreover, the SEM strategy of comparing alternative models to assess relative model fit makes it a more robust method. Nevertheless, SEM requires that several procedural steps be taken. The research framework is proposed to test the SEM technique using IBM Analysis of Moment Structures (AMOS) version 26.0 software. SEM provides a conceptually engaging way to precisely test a theory regarding relationships among variables and latent constructs. When the data is presented, and SEM can prove how well the theory fits (Hair et al., 2018). Moreover, SEM produces accurate results without measurement errors.

\section{Results}

\subsection{Demographic Profile}

Table 2 shows the demographic profile for those citizens who responded to the questionnaire. The 346 citizens who took part in this survey were $70.5 \%(\mathrm{~N}=244)$ female and $29.5 \%$ $(\mathrm{N}=102)$ male. Most citizens were less than 30 years old (34.7\%, $\mathrm{N}=120)$, followed by 31-40 years old age range $(30.6 \%, \mathrm{~N}=106)$ and the least age range were those who are more than 61 years old $(1.5 \%, \mathrm{~N}=5)$. In terms of race, $80.6 \%(\mathrm{~N}=279)$ were Malay, 9.2\% ( $\mathrm{N}=32)$ were Chinese, $5.5 \%(\mathrm{~N}=19)$ were Indian and $4.7 \%(\mathrm{~N}=16)$ were other. The information on the marital status revealed that $55.8 \%(\mathrm{~N}=193)$ were married, while $43.6 \%(\mathrm{~N}=151)$ and $0.6 \%$ $(\mathrm{N}=2)$ were others. A majority of the citizens $(52.0 \%, \mathrm{~N}=180)$ have STPM/ Matriculation/ Diploma qualification and $1.2 \%(\mathrm{~N}=4)$ with $\mathrm{PhD}$ qualification. In term of sectors, majority citizens are working at the private sector with $31.8 \%(\mathrm{~N}=110)$ and followed by public sector with $29.8 \%(\mathrm{~N}=103)$. Lastly, majority citizens had working experience less than 5 years with $26.3 \%(\mathrm{~N}=91)$, whist the least working experience is those citizens with more than 31 years old $2.9 \%(\mathrm{~N}=10)$.

Table 2. Demographic Profile

\begin{tabular}{lccc}
\hline Characteristic & & Frequency & Percentage \\
\hline Gender & Male & 244 & 70.5 \\
& Female & 102 & 29.5 \\
\hline Age & Less than 30 years old & 120 & 34.7 \\
& 31-40 years old & 106 & 30.6 \\
& $41-50$ years old & 105 & 30.3 \\
& 51-60 years old & 10 & 2.9 \\
& More than 61 years & 5 & 1.5 \\
\hline Race & Malay & 279 & 80.6 \\
& Chinese & 32 & 9.2 \\
& Indian & 19 & 5.5 \\
\hline
\end{tabular}




\begin{tabular}{|c|c|c|c|}
\hline $\begin{array}{l}\text { Mac } \\
\text { Inst }\end{array}$ & Journal of Public & \multicolumn{2}{|c|}{$\begin{array}{r}\text { Administration and Governance } \\
\text { ISSN } 2161-7104 \\
2020 \text {, Vol. } 10 \text {, No. } 4\end{array}$} \\
\hline & Others & 16 & 4.7 \\
\hline \multirow[t]{3}{*}{ Marital status } & Single & 151 & 43.6 \\
\hline & Married & 193 & 55.8 \\
\hline & Others & 2 & 0.6 \\
\hline \multirow[t]{5}{*}{ Education level } & SPM & 60 & 17.3 \\
\hline & STPM/Matriculation/Diploma & 180 & 52.0 \\
\hline & Degree & 86 & 24.9 \\
\hline & Master's Degree & 16 & 4.6 \\
\hline & $\mathrm{PhD}$ & 4 & 1.2 \\
\hline \multirow[t]{4}{*}{ Sector } & Public & 103 & 29.8 \\
\hline & Private & 110 & 31.8 \\
\hline & Self-employed & 35 & 10.1 \\
\hline & $\begin{array}{l}\text { Others (includes those who are not } \\
\text { working or those who are still studying }\end{array}$ & 98 & 28.3 \\
\hline \multirow[t]{7}{*}{ Working tenure } & No working experiences & 71 & 20.5 \\
\hline & Less than 5 years & 91 & 26.3 \\
\hline & 6-10 years & 69 & 20.0 \\
\hline & $11-15$ years & 53 & 15.3 \\
\hline & $16-20$ years & 30 & 8.6 \\
\hline & 26-30 years & 22 & 6.4 \\
\hline & More than 31 years & 10 & 2.9 \\
\hline
\end{tabular}

\subsection{Assessment on Structural Equation Modeling (SEM)}

To perform SEM, the analytical software called IBM AMOS is used. IBM SPSS software is used to screen the collected data prior to performing SEM. Then, the relationship of all variables and a detailed analysis to test the hypotheses of this research will be conducted by using SEM with the aid of the IBM AMOS software. Its popularity is attributed to its explanatory ability and statistical efficiency for model testing with a single comprehensive procedure using various measures which reduces measurement errors and provides a better understanding of the phenomenon being studied (Hair et al., 2018). In this section, we assess two important elements of SEM. Firstly the confirmatory factor analysis (CFA) and later, measurement model.

\subsubsection{Testing the Confirmatory Factor Analysis (CFA)}

CFA is a procedure to validate all latent variables in the model. The purpose of conducting CFA is to test the model fit, standard factor loadings, and standard errors. The CFA is a pre-requisite for measurement models in which both the number of factor loadings and their corresponding indicators are clearly defined (Kline, 2016). In CFA, the theory is proposed first, then tested to see how the constructs systematically represent latent variables (Hair et al., 2018). There are two methods available to execute CFA: Individual-CFA and Pooled-CFA. We decided to employ the Pooled-CFA since it is more efficient, accurate and able to monitor one set of fitness indexes for all construct in the model. More importantly, through Pooled-CFA, it could assess the correlation between variables (Awang, 2015). In the Pooled-CFA, all constructs are 
assessed simultaneously. By using this method, all constructs are pooled and linked using the double-headed arrows to assess the correlation among the constructs. The CFA model for five (5) latent variables ranges from 0.229 to 0.931 . The model also shows that the correlation coefficients among the constructs ranges between 0.025 to 0.747 , which is less than 0.900 , therefore, suggestion no multicollinearity among the variables.

\subsubsection{Testing the Measurement Model}

The first step of SEM is to test the measurement model. The result obtained from the Pooled-CFA process were assessed to form measurement model (see Figure 1). The fit indices values are Relative Chi-Square $=2.394, \quad \mathrm{RMSEA}=0.064, \mathrm{CFI}=0.963$, TLI $=0.951$ and $\mathrm{PGFI}=0.621$. As these fit indices meet the requirement as recommended by Hair et al. (2018) who suggested that if three to four of the Goodness-of-Fit (GOF) indices meets the requirement, then the model is acceptable. Therefore, in this study the measurement model is declared to be a good fit. The summary of model fit for measurement model are shown in Table 3.

Table 3. Analysis for Measurement Model

\begin{tabular}{lccccc}
\hline & \multicolumn{2}{c}{ AFI } & \multicolumn{2}{c}{ IFI } & PFI \\
\hline Fit Indices & $\begin{array}{c}\text { Relative Chi } \\
\text { Square } \\
(<\mathbf{5})\end{array}$ & $\begin{array}{c}\text { RMSEA } \\
(<=\mathbf{0 . 0 8 0})\end{array}$ & $\begin{array}{c}\text { CFI } \\
(>=\mathbf{0 . 9 0 0})\end{array}$ & $\begin{array}{c}\text { TLI } \\
(>=\mathbf{0 . 9 0 0})\end{array}$ & $\begin{array}{c}\text { PGFI } \\
(>=\mathbf{0 . 5 0 0})\end{array}$ \\
\hline 2.394 & 0.064 & 0.963 & 0.951 & 0.621 \\
\hline
\end{tabular}

Notes: AFI-Absolute fit indices, IFI-Incremental fit indices, PFI-Parsimonious fit indices RMSEA- Root mean square error of approximation, CFI-Comparative fit index, TLI-Tucker-Lewis index, PGFI-parsimonious goodness of fit index

In the measurement model, we also tested convergent validity, discriminant validity and composite reliability (CR). Convergent validity refers to a set of variables or items that are assumed to measure a construct and to share a high proportion of common variance (Hair et al., 2018). It is tested by using factor loadings and average variance extracted (AVE). Both factor loadings and AVE should measure a minimum of 0.500 which indicates high convergent validity (Hair et al., 2018). Composite reliability (CR) refers to the degree to which an instrument is measured according to the dimensions of the constructs (Hair et al. 2018). The acceptable cut-off point of CR is in between 0.600 to 0.700 (Hair et al., 2018). The result presented in Table 4.

Table 4. Analysis for Convergent Validity and Composite Reliability

\begin{tabular}{ccccc}
\hline Constructs & Items & $\begin{array}{c}\text { Factor loadings } \\
(>\mathbf{0 . 5 0 )}\end{array}$ & $\begin{array}{c}\text { AVE } \\
(>\mathbf{0 . 5 0 0 )}\end{array}$ & $\begin{array}{c}\text { CR } \\
(\mathbf{0 . 6 0 0 - 0 . 7 0 0})\end{array}$ \\
\hline Openness & O1 & 0.795 & 0.506 & 0.751 \\
& O2 & 0.758 & & \\
& O3 & 0.559 & & 0.868 \\
\hline Responsiveness & R1 & 0.867 & 0.688 & \\
& R2 & 0.854 & &
\end{tabular}




\begin{tabular}{ccccc} 
& R3 & 0.763 & & \\
\hline Transparency & T1 & 0.913 & 0.803 & 0.924 \\
& T2 & 0.870 & & \\
& T3 & 0.905 & & 0.895 \\
\hline Participation & P1 & 0.823 & 0.739 & \\
& P2 & 0.821 & & 0.745 \\
& P3 & 0.931 & & \\
\hline Satisfaction & S1 & 0.229 & 0.542 & \\
& S2 & 0.879 & & \\
& S3 & 0.895 & & \\
\hline
\end{tabular}

Discriminant validity refers to "the extent to which a construct is truly distinct from other constructs" (Hair et al., 2018). It also means that factors or items only measure one latent construct. The cut-off point for AVEs is greater than 0.500. The point of discriminant validity of the constructs is to explain whether the items are redundant. Furthermore, as presented in Table 5 by comparing the $r^{2}$ values (correlation between tested path) with the AVE value, findings showed that the $r^{2}$ of all variables' values are less than AVEs'. Consequently, it indicated that each construct is distinct.

Table 5. Analysis for Discriminant Validity

\begin{tabular}{ccccc}
\hline Tested path & $\mathbf{r}^{\mathbf{2}}$ & $\mathbf{A V E}_{\mathbf{1}}$ & $\mathbf{A V E}_{\mathbf{2}}$ & RESULT \\
\hline Openness <--> Transparency & 0.132 & 0.506 & 0.803 & Valid \\
\hline Openness <--> Participation & 0.028 & 0.506 & 0.739 & Valid \\
\hline Openness <--> Responsiveness & 0.209 & 0.506 & 0.688 & Valid \\
\hline Openness <--> Satisfaction & 0.332 & 0.506 & 0.542 & Valid \\
\hline Transparency <--> Participation & 0.005 & 0.803 & 0.739 & Valid \\
\hline Transparency <--> Satisfaction & 0.206 & 0.803 & 0.542 & Valid \\
\hline Participation <--> Satisfaction & 0.002 & 0.739 & 0.542 & Valid \\
\hline Responsiveness <--> Transparency & 0.120 & 0.688 & 0.803 & Valid \\
\hline Responsiveness <--> Participation & 0.001 & 0.688 & 0.739 & Valid \\
\hline Responsiveness <--> Satisfaction & 0.528 & 0.688 & 0.542 & Valid \\
\hline
\end{tabular}

\section{Discussion}

As this paper limit the analysis until the measurement model, we are cannot assume the entire factors namely openness, transparency, responsiveness, and participation will be influencing citizen centric satisfaction. However, we can predict findings although we are not yet tested the structural model analysis. Although, less empirical evident investigating the citizen-centric demands of transformational government model, yet we need to acknowledge the idea of transformational that brought up to assist government strategies. In this study, we modify the idea of government's transformation into citizen's satisfaction. Theoretically, openness is about acquired free access to all structured and unstructured government data (Kamaruddin \& MdNoor, 2017). As a separate component, responsiveness means government's willingness to help with citizens' requests and provide prompt services when 
needed (Osman et al., 2014). The third component - transparency, we mean that government providing information about their operations and decisions for citizens to understand how the process of the government works (Kamaruddin \& MdNoor, 2017). Lastly, the component of participation refers to citizens' contribution in government's planning and decision-making and using of government data to create better services for the community (Kamaruddin \& MdNoor, 2017).

Based on Table 6, the result show, almost all respondents agree and satisfy with the overall components that we design to capture the citizen-centric public service satisfaction. According to the OECD and ADB (2019), government able to achieve citizen-centric approach for policy making and service delivery through transparent and allowing for more active involvement among stakeholders. Through sentiment analysis and text mining approaches, Misra et al. (2018) discover that citizen-centric superior service delivery requires more integrative and responsive. Empirical results by Naswir et al. (2019) indicate that several elements inclusive satisfaction and citizen centric are key factors in the context of perceived usability of digital government services. A case study conducted by Sanka et al. (2019) revealed to have a transformational impact to government department and citizen, a smart citizen-centric system must embed the several vital elements including transparency.

In the same Table 6, the highest mean score is transparency followed by responsiveness. Perhaps the daily reported figures from Ministry of Health on Covid-19 cases started to drop simultaneously, it could be a drastic intervention by the government to allocate huge emergency funding to provide aid and to assist both the industry and society through this crisis (Prime Minister Office, 2020). Concerning crisis management, the study conducted by Marchezini (2020) propose several crucial steps, particularly on social and political aspects such as improving data and knowledge access for different sectors and engage different audiences as an unconventional people-centric approach for disaster risk reduction. Robinson et al. (2019) find that reported exposure to an emergency event increases information sharing through a variety of media and technology however, the emergency managers need to carefully disseminate information as certain sources promote the spread of information among citizen but tendency not reaching populations at risk, especially the elderly. Thus, Rådestad and Larsson (2020), suggest a more meaningful way of collaborative governance and respectful participation raise awareness and encourage individuals to prepare for and withstand crises and unburden the public authorities in crisis management.

Table 6. Descriptive Analysis on Survey Items

\begin{tabular}{lcc} 
Openness & Mean & Std Dev \\
\hline $\begin{array}{l}\text { 1. I can easily access all e-government data } \\
\begin{array}{l}\text { I am happy the public service sectors endorse "openness by } \\
\text { default" to almost all information }\end{array}\end{array}$ & 4.63 & 0.836 \\
\end{tabular}


3 I believe the information supply is understandable

$4.60 \quad 1.099$

Responsiveness

Mean Std Dev

1. I believe public service sector always "listen" to citizen's 4.90 feedback

2. I know that public service sector willingly to help the 4.83 citizen in need

3. I ascertain that public service sector is trustworthiness $4.77 \quad 1.158$ sector

$\begin{array}{llllll}1 & \text { I am pleased that public service sector is promoting } & 4.77 & 1.244\end{array}$ transparency

$\begin{array}{lllllll}2 & \text { I am sure that public service sector reveals honest } & 4.94 & 1.280\end{array}$ information

$3 \quad$ I believe transparency will build confidence

$4.84 \quad 1.241$

\begin{tabular}{|c|c|c|c|}
\hline \multicolumn{2}{|c|}{ Participation } & \multirow{2}{*}{$\begin{array}{c}\text { Mean } \\
4.68\end{array}$} & \multirow{2}{*}{$\begin{array}{c}\text { Std Dev } \\
0.991\end{array}$} \\
\hline 1. & $\begin{array}{l}\text { I think public service sector always utilizing citizens' input } \\
\text { in decision making }\end{array}$ & & \\
\hline 2. & The public service sector always probing citizen's need & 4.66 & 0.941 \\
\hline 3 & The public service sector always supports the citizens & 4.67 & 0.988 \\
\hline
\end{tabular}

Notes: Std Dev- Standard deviation

\section{Conclusion}

This present study was driven by the gap in the literature on the direct effect of the element of citizen-centric demands of transformational government model namely openness, responsiveness, transparency and participation on the relationship with citizen satisfaction in public service. The literature for these variables showed few theoretical and empirical studies on the relationship between factors stimulating condition for citizen satisfaction. To date, empirical evidences on citizen satisfaction were limited, thus inclining us to study the relationship between these variables in Malaysia context. 
We utilized a quantitative approach. A study was conducted among the 346 citizens in Malaysia. Surveys were administered through online survey (Google form). Citizen were randomly selected and asked to willingly contribute in a research project. Data collection took place in 15 June 2020 and lasted for two weeks. The current study employed the non-probability sampling category namely convenience sampling technique.

The citizens who took part in this survey were $70.5 \%(\mathrm{~N}=244)$ female and $29.5 \%(\mathrm{~N}=102)$ male. Most citizens were less than 30 years old $(34.7 \%, \mathrm{~N}=120)$, followed by 31-40 years old age range $(30.6 \%, \mathrm{~N}=106)$ and the least age range were those who are more than 61 years old $(1.5 \%, \mathrm{~N}=5)$. In terms of race, $80.6 \%(\mathrm{~N}=279)$ were Malay, $9.2 \%(\mathrm{~N}=32)$ were Chinese, $5.5 \%$ $(\mathrm{N}=19)$ were Indian and $4.7 \%(\mathrm{~N}=16)$ were other. The information on the marital status revealed that $55.8 \%(\mathrm{~N}=193)$ were married, while $43.6 \%(\mathrm{~N}=151)$ and $0.6 \%(\mathrm{~N}=2)$ were others. Additionally, the data was analyzed by using IBM SPSS software for descriptive analysis and IBM AMOS software was used for inferential analysis.

\section{Future Direction}

Despite the contributions yielded from this study, the findings should be interpreted within the limitation of the methodology employed. Firstly, this study did not run the structural model to confirm the any potential hypotheses. We believe by only testing the measurement model, we can determine the degree to which the proposed model predicts or fits the observed covariance matrix (Hair et al., 2018). Therefore, it would be beneficial for future work to analyse the structural model and confirm the hypotheses.

Secondly, this study applies the method of quantitative research design and the data collected via questionnaire survey. Although, quantitative research methods can be used to determine the degree to which individual undertake behaviours, but it limits the ability to examine the thoughts and feelings of research participants as well as the meaning that individual ascribe to their experiences. It is recommended for future research to use mixed-method approach combining both quantitative and qualitative data to better explain citizen centric satisfaction. In fact, a combination of quantitative and qualitative analyses will reinforce findings related to citizen satisfaction.

\section{Acknowledgments}

We would like to extend our gratitude to UiTM Melaka for funding this research under TEJA Grant UiTM Melaka (Ref No. GDT2020-29). Additionally, thank you to all team members for the effort, time and courage to complete the paper.

\section{References}

Agbozo, E., \& Spassov, K. (2018). Establishing efficient governance through data-driven e-government. Proceeding of the 11th International Conference on Theory and Practice of Electronic Governance (pp. 662-664), Galway, Ireland: National University of Ireland Galway.

Avery, E. J., Graham, M., \& Park, S. (2016). Planning makes (closer to) perfect: exploring United States' local government officials' evaluations of crisis management. Journal of 
contingencies and

Crisis

Management,

$24(2)$

73-81.

https://doi.org/10.1111/1468-5973.12109

Awang, Z. (2015). SEM made simple: A gentle approach to learning Structural Equation Modeling. MPWS Rich Publication.

Black, J., \& La Venture, K. (2018). The Human Factor to Profitability: Leveraging People-Centered Cultures as Meaningful Organizations. Public Integrity, 20(5), 444-458. https://doi.org/10.1080/10999922.2017.1364949

Bowie, N. (2020, March 16). Malaysia loses its grip on Covid-19 outbreak. Asiatimes. Retrieved from https://asiatimes.com/2020/03/malaysia-loses-its-grip-on-covid-19-outbreak/

Byrne, B. M. (2016). Structural equation modeling with AMOS: Basic concepts, applications, and programming. Multivariate application series (3rd ed.). Routledge.

Cai, H., \& Wang, K. (2006). Service oriented design method and practice for constructing citizen-centric public services. 2006 IEEE International Conference on e-Business Engineering (ICEBE'06) (pp. 536-540), Shanghai, China.

Das, R. K., \& Mishra, H. (2018). Smart E-Governance and Sustainable Development: Strategic Alignment Assessment Framework. Proceedings of the 11th International Conference on Theory and Practice of Electronic Governance (pp.690-692), Galway, Ireland: National University of Ireland Galway.

Fry, B. R., \& Nigro, L. G. (1996). Max Weber and US public administration: the administrator as neutral servant. Journal of Management History, 2(1), 37-46. https://doi.org/10.1108/13552529610105654

Giesbrecht, T., Scholl, H. J., \& Schwabe, G. (2016). Smart advisors in the front office: Designing employee-empowering and citizen-centric services. Government Information Quarterly, 33(4), 669-684. https://doi.org/10.1016/j.giq.2016.05.005

Grimmelikhuijsen, S., \& Porumbescu, G. A. (2017). Reconsidering the expectancy disconfirmation model. Three experimental replications. Public Management Review, 19(9), 1272-1292. https://doi.org/10.1080/14719037.2017.1282000

Hair, J., Black, W., Anderson, R., \& Babin, B. (2018). Multivariate Data Analysis (8th ed.). Cengage.

Hood, C. (2001). New public management. In Sociology (pp. 12553-12555). International Encyclopedia of the Social and Behavioral Sciences. https://doi.org/10.1007/978-0-387-93996-4_89

Jakobsen, M., James, O., Moynihan, D., \& Nabatchi, T. (2016). JPART Virtual Issue on Citizen-State Interactions in Public Administration Research. Journal of Public Administration Research and Theory, 29(4), e8-e15. https://doi.org/10.1093/jopart/muw031

Jun, D., Hagen, L., Lee, E., Lim, H., \& Kim, D. (2018). How big data contributes to the building of citizen-centric smart cities: the case of Namyangju city in Korea (pp. 1-6). 19th 
Annual International Conference on Digital Government Research: Governance in the Data Age, The Netherlands: Delft University of Technology.

Kamaruddin, K. A., \& MdNoor, N. (2017). Citizen-centric demand model for transformational government systems (pp.139). Pacific Asia Conference on Information Systems (PACIS), Langkawi, Malaysia.

Kline, R. B. (2016). Principles and practice of structural equation modeling (4th ed.). The Guilford Press.

Kopackova, H. (2019). Reflexion of citizens' needs in city strategies: The case study of selected cities of Visegrad group countries [Article]. Cities, 84, 159-171. https://doi.org/10.1016/j.cities.2018.08.004

Kumar, A. (2019). Citizen-centric model of governmental entrepreneurship Transforming public service management for the empowerment of marginalized women. Transforming $\begin{array}{llll}\text { Government- People } \quad \text { Process } & \text { 62-75. }\end{array}$ https://doi.org/10.1108/tg-03-2018-0023

Kyakulumbye, S., Pather, S., \& Jantjies, M. (2019). Towards design of citizen centric e-government projects in developing country context: the design-reality gap in Uganda. Small, 4, 11. https://doi.org/10.12821/ijispm070403

Ma, L., \& Christensen, T. (2019). Government trust, social trust, and citizens' risk concerns: Evidence from crisis management in China. Public Performance \& Management Review, 42(2), 383-404. https://doi.org/10.1080/15309576.2018.1464478

Malchenko, Y. A., \& Smirnova, M. M. (2019). What drives consumers smart? the challenge of adoption of smart city solutions. https://doi.org/10.21638/spbu18.2019.305

Malhotra, C. (2015). A Design Framework for Evolving a Citizen-Centric Information Society. In Handbook of Research on Cultural and Economic Impacts of the Information Society (pp. 25-41). IGI Global.

Marchezini, V. (2020). "What is a sociologist doing here?" An unconventional people-centered approach to improve warning implementation in the Sendai framework for disaster risk reduction. International Journal of Disaster Risk Science, 1-12. https://doi.org/10.1007/s13753-020-00262-1

Ministry of Finance Malaysia. (2020). Perlaksanaan Pakej PRIHATIN Rakyat. https://pre2020.treasury.gov.my/flipbook/laksana1/

Misra, A., Misra, D. P., Mahapatra, S. S., \& Biswas, S. (2018). Digital transformation model: analytic approach on participatory governance \& community engagement in India (pp. 1-7). 19th Annual International Conference on Digital Government Research: Governance in the Data Age, The Netherlands: Delft University of Technology. 
Mok, J. Y. (2020). Proposed non-linear relation between satisfaction with government performance and co-production: an initial empirical test. Public Management Review, 22(3), 432-451. https://doi.org/10.1080/14719037.2019.1599060

Naswir, R. Y., Maarop, N., Hasan, M., Daud, S., Samy, G. N., \& Magalingam, P. (2019). Towards a conceptual model to evaluate usability of digital government services in Malaysia. International Journal of Advanced Computer Science and Applications, 10(4), 313-322. https://doi.org/10.14569/IJACSA.2019.0100438

Nor, N. B. M., Ismail, T. N. B. T., \& Puteh, H. F. B. H. (2017). Discovering the Antecedents of Engagement for Citizen Centric Public Service Excellence. The 6th International Conference on Public Policy and Social Science (ICOPS) (pp. 809), Kedah, Malaysia: Universiti Teknologi Mara.

$\begin{array}{llllll}\text { OECD. (2019). Government at ance } & 2019 .\end{array}$ https://doi.org/doi:https://doi.org/10.1787/8ccf5c38-en

OECD, \& ADB. (2019). Government at a Glance Southeast Asia 2019. OECD Publishing. https://doi.org/https://doi.org/10.1787/9789264305915-en

Osman, I. H., Anouze, A. L., Irani, Z., Al-Ayoubi, B., Lee, H., Balc1, A., Medeni, T. D., \& Weerakkody, V. (2014). COBRA framework to evaluate e-government services: A citizen-centric perspective. Government Information Quarterly, 31(2), 243-256. https://doi.org/https://doi.org/10.1016/j.giq.2013.10.009

Rådestad, C., \& Larsson, O. (2020). Responsibilization in contemporary Swedish crisis management: expanding 'bare life'biopolitics through exceptionalism and neoliberal $\begin{array}{lllll}\text { governmentality. } \quad \text { Critical } & \text { Policy } & \text { Studies, } & \text { 14(1), }\end{array}$ https://doi.org/10.1080/19460171.2018.1530604

Reddick, C. G., Chatfield, A. T., \& Ojo, A. (2017). A social media text analytics framework for double-loop learning for citizen-centric public services: A case study of a local government Facebook use. Government Information Quarterly, 34(1), 110-125. https://doi.org/10.1016/j.giq.2016.11.001

Robinson, M. (2015). From old public administration to the new public service: Implications for public sector reform in developing countries. https://www.undp.org/content/dam/undp/library/capacity-development/

Robinson, S. E., Pudlo, J. M., \& Wehde, W. (2019). The New Ecology of Tornado Warning Information: A Natural Experiment Assessing Threat Intensity and Citizen-to-Citizen Information Sharing. Public Administration Review, 79(6), 905-916. https://doi.org/10.1111/puar.13030

Sánchez-Teba, E. M., \& Bermúdez-González, G. J. (2019). Are Smart-City Projects Citizen-Centered? Social Sciences, 8(11), 309. https://doi.org/10.3390/socsci8110309 
Sanka, S. S., Jain, G., \& Goondla, S. (2019). Electronic Citizen Service Delivery, MeeSeva-Telangana State, India (pp. 441-445). 12th International Conference on Theory and Practice of Electronic Governance, Melborne, Australia.

Sepasgozar, S. M. E., Hawken, S., Sargolzaei, S., \& Foroozanfa, M. (2019). Implementing citizen centric technology in developing smart cities: A model for predicting the acceptance of urban technologies. Technological Forecasting and Social Change, 142, 105-116. https://doi.org/10.1016/j.techfore.2018.09.012

Sicilia, M., Guarini, E., Sancino, A., Andreani, M., \& Ruffini, R. (2016). Public services management and co-production in multi-level governance settings [Article; Proceedings Paper]. International Review of Administrative Sciences, 82(1), 8-27. https://doi.org/10.1177/0020852314566008

Sneiders, E., Gunawardena, L., Ngoga, S. R., Darayathna, R., \& Byungura, J. C. (2018). Potential for Improving Public Services by Exploring Citizens' Communication to Public Organizations (pp. 265-280). International Conference on Electronic Governance and Open Society: Challenges in Eurasia, St. Petersburg, Russia.

Song, M., Kim, M., \& Favero, N. (2020). Social Class, Ingroup-Outgroup Comparison, and Citizen Evaluations: Is User Satisfaction Linked to Outcome Disparities? The American Review of Public Administration, 50(2), 205-218. https://doi.org/10.1177/0275074019874445

Van de Walle, S. (2004). Context-specific images of the archetypical bureaucrat: persistence and diffusion of the bureaucracy stereotype. Public Voices, 7(1), 3-12. https://doi.org/10.22140/pv.192

Van de Walle, S. (2016). When public services fail: a research agenda on public service failure. Journal of Service Management, 27(5), 831-846. https://doi.org/10.1108/JOSM-04-2016-0092

Van de Walle, S. (2017). Explaining Citizen Satisfaction and Dissatisfaction with Public Services. In (pp. 227-241). https://doi.org/10.1057/978-1-137-55269-3_11

Yong, J. S. (2004). Promoting Citizen-Centered Approaches to e-Government Programmes: Strategies and Perspectives from Asian Economies (pp. 6-8). Second APEC High-Level Symposium on e-Government, Acapulco, Mexico, Acapulco, Mexico.

\section{Copyright Disclaimer}

Copyright for this article is retained by the author(s), with first publication rights granted to the journal.

This is an open-access article distributed under the terms and conditions of the Creative Commons Attribution license (http://creativecommons.org/licenses/by/4.0/). 